\title{
Strategic Options to Cultural Risk Management: A Theoretical Framework
}

\author{
Nadège Firsova*, Ivan P. Vaghely \\ Institut de Recherche sur les PME, Department of Management, Université du Québec à Trois-Rivières, Canada
}

Copyright $(2018$ by authors, all rights reserved. Authors agree that this article remains permanently open access under the terms of the Creative Commons Attribution License 4.0 International License

\begin{abstract}
This paper outlines a view of cultural issues, connecting it to the risk literature. Culture, as a risk-driver of the firm, has not previously been fully explored. International business scholars tend to ignore either the external or the internal aspects of a firm's cultural environment, emphasizing only one side: either cultural diversity issues within the organization or host country cultural challenges. Using strategic management, this paper suggests that cultural risk should consider both out there according to product-market-positioning concepts and in here with the resource-based view of the firm to capture the essence of the firm's cultural dynamics. This paper proposes a theoretical framework to assess cultural risks under an enterprise-wide risk management (ERM) process to better manage such risks. The suggested framework can serve as a tool to benefit researchers as well as practitioners.
\end{abstract}

Keywords Culture, Risk, Cultural Risk Management, Enterprise-wide Risk Management Process (ERM), Strategic Management, Institutional-based View, Resource-based View (RBV), Product-market Positioning

\section{Introduction}

In recent years, public concern about the risks faced by many firms has increased (Andersen and Schroder, 2010 [2]). This concern can be explained by added uncertainty in the organizational environment due to higher frequency of major risk events over the past decade, such as terrorism, political unrest, energy price shocks, large-scale involuntary migrations, or natural disasters. Risk stems from every activity that a firm undertakes, including those directly related to the firm's international business activities (Fraser and Simkins, 2010 [34]). One of the primary objectives of firms operating internationally is to manage risk (Ghoshal, 1987 [39]), and an integrated risk management process should be regarded as a core skill by every firm (Miller, 1992 [79]; Bishop, 1996 [11]; Andersen and Schroder, 2010 [2]; Fraser and Simkins, 2010 [34]; Hopkin, 2012 [51]).

Fraser and Simkins (2010) [34] classify risks according to their nature, either financial or non-financial. Financial risk involves the relationship between an individual or an organization and an asset or the expectation of an income that may be lost or damaged (Vaughan, 1997 [122]). This risk reflects the firm's profitability level, its debt load and interest coverage, the firm's capacity for indebtedness, its financing contracts (such as redemption dates and restrictive clauses), the firm's capacity for reinvesting by the current owners (St-Pierre and Bahri, 2006 [112]), and is related to credit or the market. However, financial risks are not the only risks faced by organizations. Risks that are not related to credit or the market are non-financial. Events such as the Brexit vote (political and economic risk), the Fort McMurray wildfire (disaster risk), hacking and cyber-attacks (technology risk) or the Home Depot commercial failure in China (cultural risk) serve to highlight the fact that the scope of risks extends beyond credit and the market. While financial risks are well defined and accounted for in a company's records, many of the non-financial risks are less precise and, therefore, much harder to describe, predict, and measure (Andersen and Schroder, 2010 [2]).

Culture as a risk-driver has not previously been fully explored in the extensive international business literature. Culture is generally viewed as a foreignness, and cultural dynamics is seen as a liability (Hymer, 1976 [54]) or a disadvantage that negatively affects the successful performance of a firm abroad (Luo and Mezias, 2002 [73]). Indeed, a firm operating internationally can face difficulties related to a lack of knowledge of local best practices and of the local competitive environment when compared to local firms (Hymer, 1976 [54]; Johanson and Vahlne, 1977 [59]; Rugman and Verbeke, 2004 [98]; Zaheer, 1995 [127]; Rugman and Doh, 2008 [99]). A firm may fail in its foreign operations due to a lack of 
understanding of marketing and distribution channels in the host country (Doole and Lowe, 2008 [25]). This liability of foreignness can lead to a low performance ( $\mathrm{Lu}$ and Beamish, 2006 [72]; Nakos and Brouthers, 2002 [81]) and a high risk of exit among foreign subsidiaries of multinational firms (Zaheer, 1995 [127]).

Brannen (2004) [14] presented a paradox regarding what we know about foreignness. Using the example of Disney's attempt at theme park internationalization, with success, in Tokyo, Japan, and with mitigated results in Paris, France, foreignness was seen as an asset and not as a liability. Cultural distance (Kogut and Singh, 1988 [64]), which has been considered to be a key indicator of firm foreignness (Barkema, Bell, and Pennings, 1996 [8]; Child and Markoczy, 1993 [20]; Gomez-Mejia and Palich, 1997 [40]), had a reverse effect in Disney's cases of internationalization, where there was a greater cultural distance between the United States and Japan than between the United States and France. This paradox suggests that even though we know a lot about foreignness, there is still something that we are missing. Taken together, these studies raise an important question: how can culture be an advantage as opposed to a liability? A better understanding of how a firm can generate benefits and mitigate the negative effects of culture is required. The primary goal of this study is to help fill this important gap in our knowledge.

The paper outlines a view of the cultural issue, connecting it to the risk literature. The unit of analysis is the firm. This paper's contribution is to propose an integrative conceptual framework to help assess cultural risks faced by a firm from its external and internal environments. As a part of an enterprise-wide strategic risk management process (ERM), cultural risks can be introduced to a wide range of concepts and management techniques by correctly identifying the potential risks and prioritizing the appropriate responses, considering both the potential for downside losses and upside gains of all risks.

This paper begins with a review of the pertinent writings on risk and risk management. It further discusses the concept of culture and the place that culture takes within organizations. Next, it defines the concept of cultural risk and explains why this risk needs to be integrated into a firm's strategic risk management process. This section also outlines the limitations of cultural risk measurements; however, its further development is not the intent of this paper. Then, the strategy's resource-based view (RBV) and product-market positioning are used as platforms from which to open up internal and external perspectives to capture the essence of the firm's cultural dynamics. This, in turn, helps to theorize some strategy-based paths for cultural internal and external risk management. A unifying cultural risk management conceptual framework is suggested.

\section{Extant Research and Some Definitions Recalled}

\section{Risk and Risk Management}

Risk has been defined in many ways in the risk management literature. Although many definitions exist, the common elements may be identified as concepts that seem to be based on the same foundation, despite differences in terminology. For example, Kaplan and Garrick (1981) [60] have identified three questions to define risk: What can happen? How likely is it that it will happen? And finally, if it does happen, what are the consequences?

The International Standards Organization (ISO) defines risk as the combination of the probability of an event and its consequence, noting that the consequence may be either positive or negative. Meanwhile, managers generally associate risk with negative outcomes (March and Shapira, 1987 [78]). From the strategic management point of view, a risk is inescapable in each business activity (Chapman, 2011 [18]) because nearly all operational tasks and processes are viewed through the prism of risk (Hunt, 2001 [53]). The end result of successful strategic direction setting is the firm's capacity to manage risks because this is the only way to improve performance (Chapman, 2011 [18]). Moreover, with a prudent risk management program in place, a firm can gradually stabilize its profitability (Shimpi, 2001 [110]).

Risk management has been defined as a holistic process that is initiated by an organization and which integrates identification, analysis and treatment of risk (Aubert and Bernard, 2004 [7]). This has long been considered to be a standard management activity. However, it has been limited to those exposures that can be observed, measured, and financed through insurance and other financial hedging products, including derivative instruments, or that can be contained through implementation of internal control systems (Andersen and Schroder, 2010 [2]) such as a real-options process. The current business environment is complex and in constant change (Lipovetsky, 2004 [71]), giving rise to new opportunities for organizations. At the same time, the range of risks that firms feel that they need to manage has vastly been expanded and continues to grow (Hunt, 2001 [53]). Risk management requires a broader approach because of the diversity of risk, such as a multinational workforce, profound social instability, slowing economic growth, or technology development (Keegan, 2002 [62]; Hillson and Murray-Webster, 2007 [45]). These sometimes-interdependent risks have become accepted and embedded in society with startling speed. The integrated enterprise-wide strategic risk management process, or ERM, that identifies and assesses the many types of uncertainties relevant to the firm's environment is a response to the sense of inadequacy in using a silo-based approach to manage interdependent risks (Miller, 1992 
[79]; Shimpi, 2001 [110]).

\section{Enterprise-wide Risk Management Process}

Risk management practitioners first started talking about integrated risk management in the 1990s (Miller and Bromiley, 1990 [80], Miller, 1992 [79]; Waring and Glendon, 1998 [125]). ERM has been defined as 'a set of components that provide the foundations and organizational arrangements for designing, implementing, monitoring, reviewing and continually improving risk management throughout the organization' (ISO Guide 73, 2009 [56]). ERM, as an integral part of the strategic planning process, has been introduced with the purpose of assessing corporate exposures more systematically within an integrative framework. This is done by considering both the potential for downside losses and upside gains offered in an uncertain moment (Andersen and Schroder, 2010 [2]) The ERM integrative framework considers the risk management cycle - comprised of risk identification, risk analysis, risk evaluation and risk responses - as a central process element (Fraser and Simkins, 2010 [34]; Andersen and Schroder, 2010 [2]; Chapman, 2011 [18]). Finally, ERM explicates how risk management responses should comply with a firm's overall strategic objectives (Andersen and Schroder, 2010 [2]).

\section{The Concept of Culture}

Does culture represent a risk for an organization and, if so, to what extent? We will review some of the clarifications and definitions to better understand the concept of culture before we attempt to answer this question. Research on culture dates back to Tylor (1924) [117] and related inquiries have multiplied at an accelerated pace, to a point that Kroeber and Kluckhohn (1952) [68] identified 164 different definitions of culture. At the beginning, the examination of culture was associated with anthropology, focusing on the origins and composition of culture. Herskovits's (1967) [41] or Malinowski's (1968) [77] studies are good examples of these studies of culture. As time passed, for anthropologists it no longer seemed possible to study culture as a self-enclosed, coherent, patterned field of meaning (Rosaldo, 1997 [97]). Other sciences rapidly followed anthropology by proposing a comparative approach between nations and cultures.

Tylor (1924) [117] defined culture as that complex whole which includes knowledge, belief, art, law, morals, customs, and any other capabilities and habits acquired by an individual as a member of society. From the beginning, this definition of culture introduced some confusion by trying to bring together a system of rules, traditional ways of behaving or beliefs, and acquired skills, experience, and specific internal properties of the individual. Consequently, no uniform model of culture exists. Some authors have followed Hofstede's (1991, [46] 2001 [47], 2010 [49]) positivist approach by refining some of his cultural dimensions (Trompenaars and Hampden-Turner, 1998 [116]; House et al., 2004 [52]) or his methodology (Sivakumar and Nakata, 2001 [109]; Schwartz, 2007 [102]; Yeganeh, 2011 [126]). With this essentialist paradigm of culture, a singular national identity is often a determinant factor and culture is considered to be static, holistic, bounded, and deterministic (Nathan, 2015 [82]). A major advantage of viewing culture from a positivist perspective is that it possesses distinct characteristics that can be measured and even manipulated (Leung and Morris, 2015 [69]; Kogut and Singh, 1988 [64]).

Others believe that culture is not static (D'Iribarne, 2009 [24]). Scholars such as Sackmann et al. (1997) [100] or Søderberg and Holden (2002) [111] have highlighted the idea that other cultures than a national culture are also active participants. To other scholars cultural knowledge is relative and contextual, and the context must be taken into account (Holden, 2002 [50]; Søderberg and Holden, 2002 [111]; Gerhart and Fang, 2005 [35]; Dupuis, 2014 [27]). In this view, cultural studies are primarily the study of contexts rather than culture, insofar as contexts are produced in social practice (Denzin and Lincoln, 2000 [23]). From this interactionism perspective, or a non-essentialist paradigm (Nathan, 2015 [82]), culture is dynamic with continuity and change, internally driven, heterogeneous, changeable, and with blurred boundaries. Consequently, it is not easy to measure.

From a situated dynamic perspective, Leung and Morris (2015) [69] advocated the need to consider a more complex construct of culture. In light of their recent study, scholars perhaps need to consider not just the values in the construct of culture, notably Hofstede's dimensions, but should also examine the typical situations and identify relevant schemas (Gioia, 1986 [36]; Gioia and Manz, 1985 [37]; Gioia and Poole, 1984 [38]; Vygotsky, 1962 [124]; Luria, 1976 [76]) and norms (Sherif, 1936 [107]; Asch, 1956 [5]; Fishbein and Ajzen, 1975 [33]; Buchtel and Norenzayan, 2008 [15]; Norenzayan et al., 2002 [85]) that shape decision making and intercultural interaction. Some other constructs of culture may also exist. While this perspective provides a richer description of cultural dynamics and offers insight not captured by the positivist approach to culture, it needs further development, notably to address its measurement issues. How to leverage such insight has to be pursued in future research. International business executives need to better understand a more complex construct of culture in order to address its influence.

\section{Culture as a Liability of Foreignness}

In the borderless realities of a globalized business economy, where individuals from different cultures are intermingled in organizations, culture has a deep impact on the variety of a firm's activities, especially on its international development. Culture viewed as a liability of foreignness represents extra costs of doing business abroad incurred by a firm operating in a foreign market (Hymer, 
1976 [54]; Luo and Mezias, 2002 [73]). The Oxford English Dictionary defines foreign as that which is 'of, from, in, or characteristic of a country or language other than one's own' and, therefore, seeming strange. If the parent company is significantly foreign from its subsidiary, then the transferred firm's assets may not be fit for the receiving context in the host country (Hymer, 1976 [54]; Kostova, 1999 [65]; Kostova and Roth, 2002 [66]; Asmussen and Goerzen, 2013 [1]).

Problems resulting from the liability of foreignness in the firm operating overseas abound. These range from simple events - such as misunderstandings through the communication process-to complex cultural misalignments when an organization's entire systems are transferred-resulting, for example, in the Daimler-Benz Chrysler merger failure because of a gap in organizational cultures. Daimler-Benz is a German company that could be described as conservative, efficient, and safe, while Chrysler is known as daring, diverse, and creative. Moreover, Daimler-Benz was much more imposing and tried to dictate the terms on which the new company should work (Appelbaum, Roberts and Shapiro, 2009 [4]). It was this failed partnership between Daimler-Benz and Chrysler that first rang the alarm bells that cultural factors cannot be ignored on a global level, especially not in mergers and acquisitions.

Another example comes from the business literature regarding the Home Depot commercial flop in China. A strong economy in China had created a middle class with money to spend, which led to a housing boom. Looking to expand internationally, Home Depot spotted a big opportunity in the Chinese market. But all of its efforts failed, largely because of considerable cultural problems. Unlike North America where labor costs are high, labor is cheap in China and so people tend to hire contractors to do everything. Therefore, the cheap labor do-it-for-me culture in China eliminated the do-it-yourself culture that Home Depot was built on.

Like Home Depot, the online auction eBay saw a very attractive market in China. Its global strategy is to grow via acquisitions. The company entered the Chinese market in 2004 by purchasing a local online trading company called Eachnet.com - which enjoyed a 90\% market share in China at the time. eBay took over the site, re-designed it to conform to eBay's look and functionality, then spent millions of dollars on advertising to maintain the previous site's market share. Meanwhile, Alibaba, the business-to-business auction site and eBay's major rival in China, decided to defend its turf by launching a competing consumer auction site. They called it Taobao - which was Chinese for "digging for treasure." The company knew one critical thing: in China, goods are bought and sold based on personal bonds and mutual obligation. The Chinese call this guanxi. Taobao's auction platform offered guanxi in the form of a chat feature that allowed buyers and sellers to get to know each other. On Taobao, buyers spent an average of 45 minutes using the instant messaging to ask sellers about themselves and their products before purchasing. eBay didn't appreciate the important of guanxi and had no mechanism for encouraging it. As a result, in two years, their market share shrank from $90 \%$ to $10 \%$, and the company pulled out of China.

\section{Foreignness as an Advantage}

Brannen (2004) [14], in Disney's example of theme park internationalization in Tokyo, presented foreignness as an asset and not as a liability. The owners of Tokyo Disneyland viewed the park as an exact replica of the original Disneyland in Anaheim, California because they wanted the Japanese visitors to feel that they were taking a foreign vacation by coming there. To them, Disneyland represents the best that the United States had to offer. Similarly, Caprar (2011) [16], in his study on multinational corporation employees, highlights that in countries where host-country employees display a predominantly positive stance towards the home culture of the firm, the particular cultural profile of the host-country employees might represent a compensatory location advantage because in such locations the foreignness of the company might be an asset and not a liability.

\section{Cultural Risk and Cultural Risk Measurement}

Responding to our previous question of whether culture represents a risk for a firm, we recognize the impact of culture on a firm's activities. As risk relates to a firm's environment and can have a negative or a positive outcome, it may be related to an opportunity (gain) or a loss for the organization. Following a logical sequence, cultural risk can be defined as the opportunity (gain) or loss faced by the firm related to an understanding of its cultural environment (Firsova, Vaghely, and Arcand, 2015 [32]). Being non-financial in nature, cultural risk is less precise and more uncertain, and is often ambiguous, which make it harder to describe, predict, or measure.

From the perspective of a firm's cultural risk measurement properties, the construct of cultural distance (Kogut and Singh, 1988 [64]) has long been considered as a key indicator of a firm's foreignness (Zaheer, 1995 [127]; Barkema et al., 1996 [8]; Child and Markoczy, 1993 [20]; Gomez-Mejia and Palich, 1997 [40]). It is a composite index based on the deviation along each of Hofstede's (1991) [46] cultural dimensions, focusing on the cultural distance between countries. Cultural distance has been applied in international business for foreign investment expansion, choice of entry mode and the performance of foreign invested affiliates, among others. Furthermore, the construct of cultural distance promotes a positivist view of cultural differences where culture is viewed as static, bounded, and deterministic. While convenient and easy to use, the construct has issues in terms of conceptualization, including potential differences between national and organizational cultures, and intra-cultural variety (Shenkar, 
2001 [104]). Despite criticism, the indicator of cultural distance continues to be used extensively and it has become so entrenched that it has spawned followers with knowledge distance (Farjoun, 1998 [31]), institutional distance (Kostova, 1999 [65]), or technological distance (Vassolo, Anand, and Folta, 2004 [121]).

Another stream of thought demonstrates that cultural friction, the new construct offered as a replacement of culture distance (Shenkar, Luo, and Yeheskel, 2008 [105]), can be curtailed through a series of managerial actions around the points of cross-border contact (Luo and Shenkar, 2011 [75]). Adopting a social constructionist approach, cultural friction is a substitute construct that is centered on the actual encounter of cultural systems within a context of power relations and potential conflict between a multinational enterprise and its host country constituencies. Shifting away from viewing culture in terms of its differences, cultural friction captures the magnitude of interaction between the cultural systems engaged in cross-border businesses (Luo and Shenkar, 2011 [75]). However, due to its dynamic nature, the indicator of cultural friction is not easy to use.

\section{Integrating Cultural Risk into the ERM Process}

Proposition 1: Incorporating cultural risk into the ERM of strategic planning can help to better manage these risks by identifying potential risks and by providing multidimensional treatment of these risks, prioritizing the appropriate responses, considering both the potential for downside losses and upside gains of all risks.

A firm's effective strategy deals with the alignment of the organization to its uncertain environment (Miller, 1992 [79]). Being uncertain, the firm's cultural dynamic environment needs to be under the firm's control and should be included in the strategic risk map since responses to those risks have to be developed. The emphasis on particular cultural issues rather than a multidimensional treatment of cultural risks is a significant shortcoming in much of the existing international business literature. Many organizations continue to address some cultural risks in silos where management emphasizes particular cultural events, such as foreign market entry mode flops, cultural diversity issues, marketing, or communication difficulties, each conducted as narrowly focused and fragmented activities.

With a large number of possible cultural risks, it can be difficult for a firm to address the impact of each risk efficiently. Furthermore, this perspective, which can provide a particular view, tends to isolate cultural risk from other interrelated uncertain variables, such as the political, economic, or legal risks of a host country. Since risks are inherent in all of the strategic decisions and business activities performed by a firm, cultural risk management practices should be an integral part of the corporate business process where all risks are categorized according to the project's time, cost, and performance constraints.
The prioritization of risks management can also be established.

The potential of strategic ERM, applied across broader categories of liabilities and assets, is appealing. This approach provides a deeper risk narrative that is more capable of preventing black swan risks (Taleb, 2010 [113]) - unpredictable or unforeseen events - typically with extreme consequences. As part of ERM, cultural risks are not overlooked but are instead identified, analyzed, and can be further managed without the exclusion of other interrelated risks. Finally, ERM can create a combined and more efficient exposure to risk that differs from the sum of the individual risks.

Combined research in risk management and strategic management can also provide an opportunity to articulate some paths to cultural risk management that have previously gone undetected.

\section{Contributions from Strategic Management}

The attempt to integrate culture in strategic management is not new. The strategic management's institutional-based view suggests that culture is a substratum of institutional arrangements (Peng, Wang, and Jiang, 2008 [92]; Hofstede et al., 2002 [48]; Scott, 1995 [103]; North, 1990 [86]). According to the institutional-based view model, strategic choices are not only driven by industry conditions and a firm's capabilities but are also a reflection of the formal and informal constraints of a particular institutional framework that managers confront (Carney, 2005 [17]; Chelariu, Bello and Gilliland, 2006 [19]; Zhou, Tse and Li, 2006 [129]; Hill, 2007 [44]). In other words, institutions directly determine what tools they have available as they struggle to formulate and implement strategy, and this helps them to create a competitive advantage (Ingram and Silverman, 2002 [55]). Culture, according to this view, is part of the informal institutions in the environment that underpin formal institutions (Redding, 2005 [96]).

Although the numbers of scholars integrating the institutional-based view is constantly growing, the major shortcoming of this perspective is that it mostly focuses on emerging economies, and particularly on China.

\section{Internal and External Views of Cultural Risk}

Proposition 2: Strategy's resource-based view (RBV) and product-market positioning open up internal and external views of cultural risk. This, in turn, helps to propose some strategy-based paths for cultural internal and cultural external risk management.

RBV and product-market positioning are well-established perspectives in the strategy literature. Since the early 1990s, a perspective-relevant debate has been driven by two opposite but not necessarily conflicting perspectives on how to acquire competitive advantage: 
either through the firm's positioning in the marketplace or by the firm's internal resources. This is a debate between Porter's (1979 [93], 1980 [94]) activity-based view and the RBV, which is inspired by Prahalad and Hamel's (1990) [95] article on the core competencies of organizations.

According to Porter $(1979,[93] 1980$ [94]), the superior performance of a company is derived from its competitive advantage in its unique product-market positioning in the industry's relevant marketplace, in terms of product-cost and market-differentiation. This product-market positioning is based on the activities of the company operating in specific industries with specific value-chains. Going through the value-chain of organizational activities will add more value to the product and services than the sum of the added costs of these activities. Thus, the company will gain marginally superior rent-value for that product or service. If these activities run efficiently, the company gains a cost-competitive advantage on the product or service.

The RBV, which is a firm-internal strategic perspective, suggests that the resources, dynamic capabilities, and competencies of the firm (Sanchez, 2001 [101]) achieve superior performance. Porter's product-market or external positioning, in comparison, attempts to clarify the understanding of the impact of a firm's external environment on performance.

Similarly, from a strategic management point of view, it is helpful to view cultural risks from two different perspectives. The first is a firm's internal cultural risk, which is RBV driven and related to human resource management policies and practices by activities such as multicultural teams' management. The second is a firm's external cultural risk, which is product-market driven and whose related risks are possibly mitigated by Ashby's (1956) [6] requisite variety principle where internal resource management variety meets the required external product-market cultural variety.

Based on strategy's RBV, the internal cultural risk is generated at organizational-level and includes but is not limited to the cultural diversity issues. It also manifests in a firm's practices and cultures including, for example, language and behavioral norms, employment policies, and decision-making patterns (Luo and Mezias, 2002 [73]).

In the international business literature, cultural diversity in organizations is often associated with conflicts, misunderstandings, and low performance in organizations (Bivens and Lowell, 1966 [12]; Killing, 1983 [63]; Shenkar and Zeira, 1992 [106]). Culturally diverse work groups have a higher level of conflict (Pelled, 1996 [91]), and less cooperation and cohesiveness (Jehn, Northcraft and Neale, 1999 [58]), and are unable to define common goals and aspirations (O'Reilly, Snyder and Boothe, 1993 [88]). Other studies have found that cultural factors are an advantage in a business environment, on the condition that they are well managed (Karjalainen, 2010 [61]; Thatcher and Jehn, 1998 [114]; Van Knippenberg, De Dreu and
Homan, 2004 [120]). Viewed as a firm's strategic resource (Van Knippenberg, De Dreu and Homan 2004 [120]; Holden, 2002 [50]), cultural diversity relates to human resource management, which is a strategic function of organizations (Schuler and Rogovsky, 1998 [108]) enabling the organization to better perform by meeting the external market's cultural diversity.

Cultural diversity management is relevant to individuals who are expatriated and also to those who come in contact with individuals from other national cultures, such as management-team members. This internal view includes managerial roles analysis, with a particular emphasis on the management of global teams, such as a multinational team's dynamics when working with different nationalities on international projects. A firm-internal analysis, like core competences, is based on specific internal resource leveraging, including cultural diversity. It can help to fuel strategic decisions at the organizational-level by emphasizing how a company should compete.

The external cultural risk is the probability and cost consequences that a business will go wrong as a result of a lack of understanding about performing in a new, culturally foreign market. The external cultural risk is generated by country-level context settings and is related to the product-market positioning strategy of the company competing in a foreign market. In the international business literature, it relates to the dynamics of product packaging, distribution, and branding in international markets (De Mooij, 2010 [22]; Usunier and Lee, 2009 [118]; Kotabe and Helsen, 2009 [67]; Theodosiou and Leonidou, 2003 [115]). The external cultural risk occurs when a particular product or service is introduced to a new market without knowing a country's context, way of doing business, or how a product or service will be perceived by the customers. Ultimately, the external cultural risk may lead to productivity and efficiency losses, which emerge as a result of the management's inability to operate effectively in a foreign market environment.

Overall, the external cultural risk analysis can help to fuel strategic decisions at the country-level. It emphasizes where a company should compete and what is culturally important when it does compete there.

The international business literature suggests a variety of conditions that can mitigate the negative effects of these cultural factors. Foremost among these is the firm's previous experience in foreign expansion (Barkema et al., 1996 [8]; Delios and Beamish, 2001 [21]) or in the host country itself (Barkema, Shenkar, Vermeulen and Bell, 1997 [9]; Johanson and Vahlne, 1977 [59]; Luo and Peng, 1999 [74]). According to another approach, more attention should be given to a search for mechanisms to compensate for the liability of foreignness. Zaheer and Mosakowski (1997) [128] suggest that foreign firms might be able to partially compensate for the liability of foreignness through factors such as capital availability from its parent firm. 
Therefore, there are two different views of cultural risk. The two views require different approaches to carry out analysis in order to mitigate them. Given that cultural risk cannot entirely be avoided, it is important for a firm to consider how best to reduce it. However, the above mentioned scholars tend to emphasize only one side of cultural risk: either cultural diversity issues inside the organization or host country culture challenges. We suggest that, to be effective, a cultural risk management strategy should be developed in view of the firm's overall strategic planning to capture the firm's both internal and external cultural dynamics. Adjacent cultural risk activities should be integrated into corporate business processes in an ERM context. To illustrate, a conceptual framework is presented in the following section.

\section{Towards an Integrated Conceptual Framework}

The examples of the Daimler-Benz Chrysler merger failure or Home Depot's unsuccessful foreign expansion in China highlight the poor results when cultural risks are ignored or ineffectively managed. In these cases, cultural risk activities were not linked or integrated with the ERM of strategic planning, where all risks are categorized by project. Consequently, these risks were overlooked, creating dangerous blind spots in the strategy execution. Following these failures, there have been numerous calls for improvement in overall cultural risk oversight, with a particular emphasis on strategic risk management. A better understanding of how a firm can generate benefits and mitigate the negative effects of culture requires a framework that recognizes both country-level effects and organizational-level cultural dynamics to better manage these risks. The challenge, as well as opportunity, for organizations is to embed cultural risk management explicitly into the ERM of the strategic management processes of the firm so that strategy and risk, including cultural risk, mindsets are one and the same (see Figure 1)

Both risk management and strategic management refer to a sequential analytical chain of activities that include: identification of internal and external environmental conditions; assessment of the potential consequences of those conditions; and, formulation of corporate actions to achieve strategic objectives within reasonable risk boundaries, based on extensive analysis of firm's strengths, weaknesses, opportunities, and threats (SWOT), and follow-up activities to monitor corporate performance and environmental developments. The SWOT analysis reflects the firm's mission statement and strategic objectives. It is the output of the internal environment analysis that identifies the strengths and weaknesses. Meanwhile, the external environment analysis identifies opportunities and threats where weaknesses and threats are de facto engaged in explicit analysis of strategic risks. The level of process activity is part of the strategic plan. It includes the business plan and the corporate risk management corresponding to the initial identification of important environmental risks.

The initial risk analysis and assessments in the risk management process are complementary to the environmental analysis that is pursued in the strategic management process. These complementary processes provide the basis for policy guidelines applied by the organization (Andersen and Schroder, 2010 [2]). Given the dynamic nature of the environment in which firms currently operate, the strategic risk management ambition is about underpinning strategic decision-making.

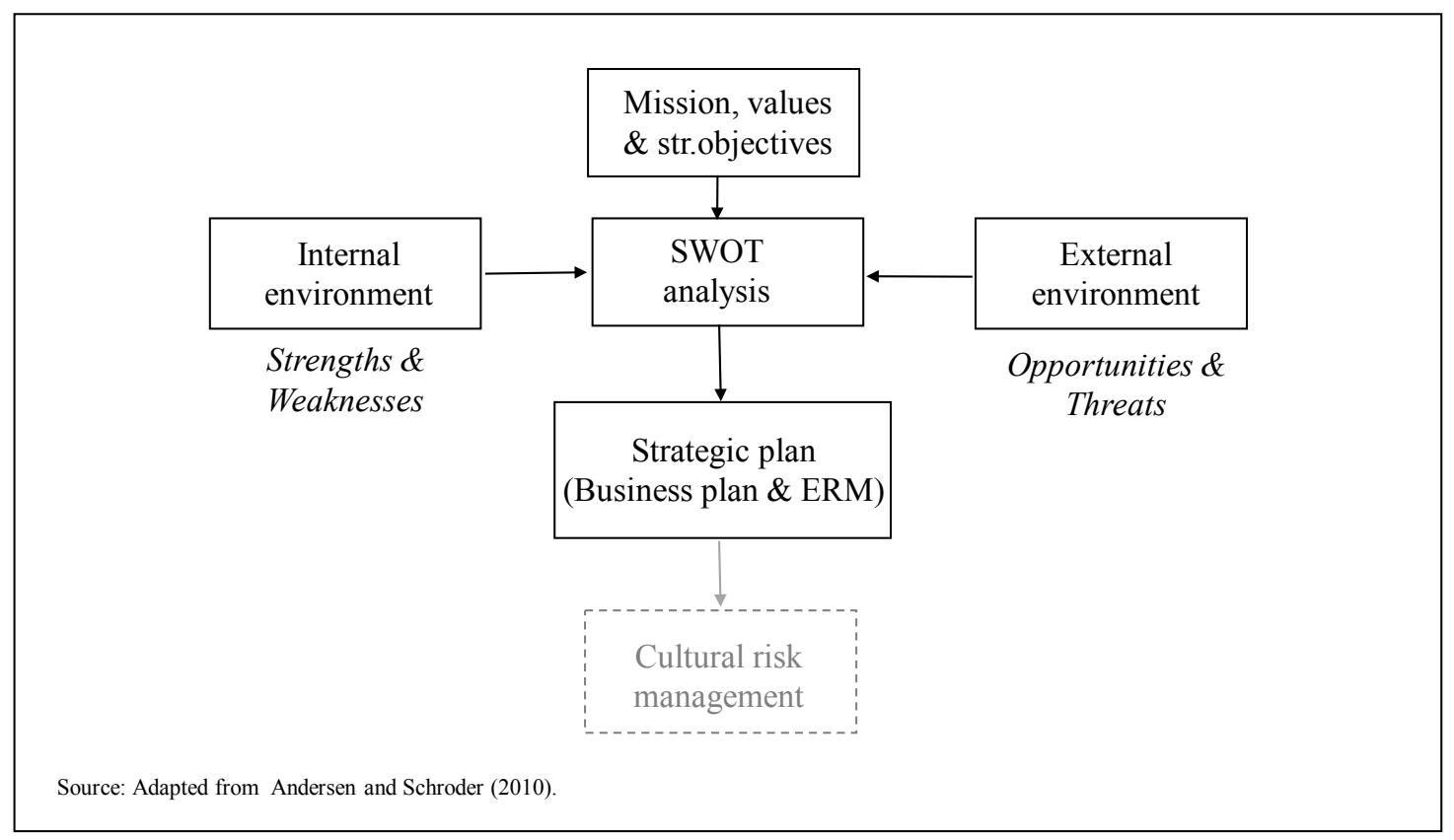

Figure 1. Integrating the strategic management and risk management processes 
The next level of process activity is the subsequent management of all of the identified risks related to strategic projects involved in a strategic plan, where concrete steps are taken to achieve the intended outcomes. This corresponds to the pursuit of strategic objectives and requires actions in line with the firm's long-term strategy. Depending on the nature and size of the project, each project framework can include different economic, political, legal, technological, or cultural risks. Under an ERM umbrella, these risks are analyzed, evaluated, and further managed. Figure 2 below provides an example of the cultural risk management.

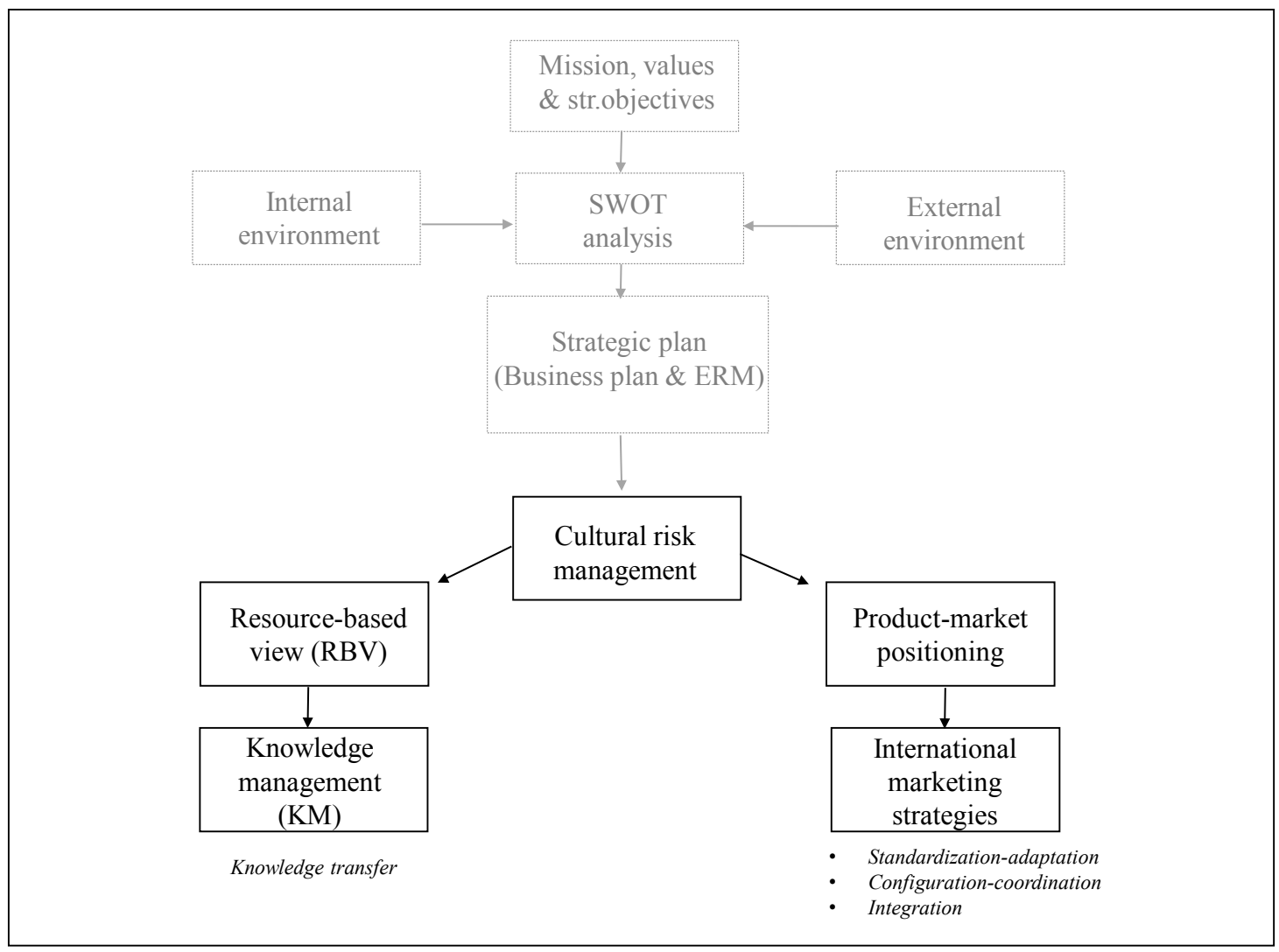

Figure 2. Integrating the cultural risk in the risk management processes

\section{A Firm's Internal Cultural Risk Management}

In strategic management, the RBV seeks to improve the firm's performance by leveraging its internal resources, dynamic capabilities, and competencies. The firm's competences, or the firm's knowledge, are a critical organizational resource (Dunning, 1993 [26]) and they provide the firm with a competitive advantage (Nonaka and Takeuchi, 1995 [83]; Nonaka and Von Krogh, 2009 [84]).

Drawing on the firm's RBV, cultural diversity, representing a potential internal risk for organizations, when viewed as a form of organizational knowledge can be moderated through the knowledge management (KM) processes. This gives rise to a specific managerial overtone or connotation, and gives focus to knowledge sharing and knowledge transfer. This view presents cultural diversity management as a form of $\mathrm{KM}$ where culture is considered as a form of organizational capital (Barney, 1985 [10]) and a form of organizational knowledge (Holden, 2002 [50]).
Internal cultural risk management is, therefore, a form of organizational KM.

Understanding the process of cultural knowledge transfer is especially important. Because a firm's competitive advantage resides in their ability to create explicit knowledge out of tacit knowledge (Nonaka and Takeuchi, 1995 [83]), transforming cultural diversity into a corporate asset rather than a source of misunderstanding, conflict, and poor performance is a critical task. Individuals hold cultural knowledge and when it is shared through mental models (Gioia, 1986 [36]; Gioia and Poole, 1984 [38]; Vaghely and Julien, 2010 [119]), it can be converted into a resource for underpinning distinctive competency and this leads to a sustained competitive advantage. As well, in entering and expanding in foreign markets, the decisions relating to the desired amount of knowledge that a firm is willing to share need to be considered at the strategic planning process level with regard to the level of risk the firm is willing to consider. 


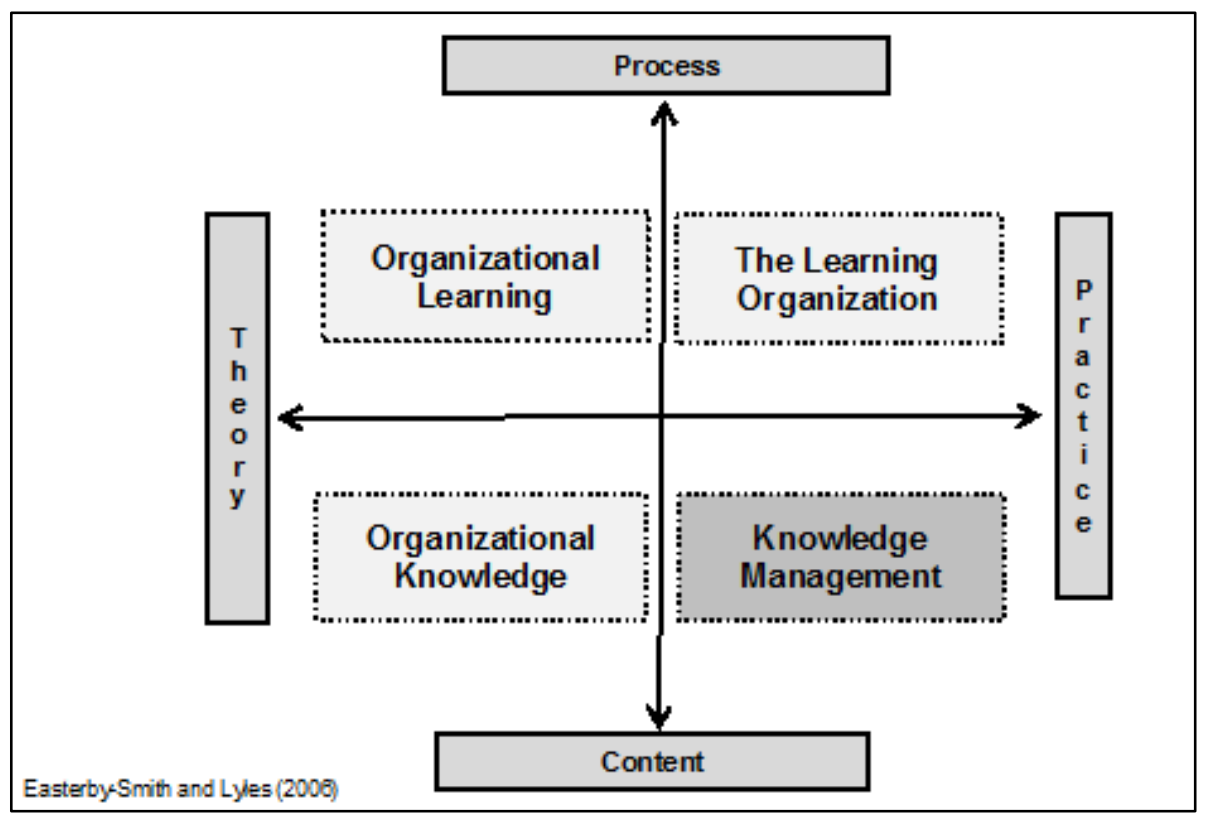

Figure 3. Easterby-Smith and Lyles' knowledge matrix

Easterby-Smith and Lyles' (2006) [28] matrix (Figure 3) places the knowledge practiced in organizations in a four-field matrix using the dichotomies of theory-practice and content-process, where: organizational learning is in the theory/process quadrant; learning organization is in practice/process; organizational knowledge is in theory/content; and knowledge management is in practice/content, the quadrant of knowledge-transfer. This is a practical way to apply most of the organizational experience that is related knowledge-transfer and which occurs from, for example, expatriates and repatriates $\mathrm{KM}$; or for that matter, from any other knowledge related experience transfer.

Organizations also use the learning organization practice-process quadrant for knowledge transfer or for downloading to knowledge databases for other than experience-related knowledge, such as the firm's expertise. For culture relevant experience transfer, the practice-content quadrant is used. These theory-specific quadrants relate to research.

To put the matrix in practice, expatriates and repatriates, viewed as a source of organizational knowledge, can be good examples of facilitating the transfer and redeployment of a parent firm's knowledge to its local subsidiary. There is some evidence to suggest that expatriates play a positive role in transferring parent-level, location independent, knowledge in terms of enhancing a subsidiary's competitive advantage (Fang et al., 2007 [29]; Fang et al., 2010 [30]). Thus, using the expatriates' valuable, firm-specific, and inimitable knowledge can be beneficial to subsidiaries.

Another example of a successful knowledge transfer is Booz, Allen \& Hamilton's global knowledge system, called Knowledge Online 2.0 (KOL). This is a dynamic, interactive repository of consultants' knowledge and experience that can be accessed by staff members all over the world using a Web browser. The tool allows every individual in the company to facilitate the creation and sharing of knowledge throughout the firm, without the underlying infrastructure acting as a barrier to the flow of information.

Clearly, a number of factors, such as the lack of personal relationship, the absence of trust, the lack of time to share knowledge, or the intolerance for mistakes, can retard, erode or prevent knowledge transfer, and create resistance and misunderstandings. This can be partially explained by the sometimes-poor structures and networks that are used to mediate and diffuse knowledge within the organizational environment. These inhibitors should be fixed because the firm's overall success in creating the competitive advantage depends on its ability to successfully transfer and effectively use valuable knowledge.

While this knowledge-based approach in international business emerged in recent research (Zaheer 1995 [127]; Holden, 2002 [50], Søderberg and Holden, 2002 [111]; Boyle, Nicholas and Mitchell, 2012 [13]), further research is required to better understand how cultural knowledge can be shared and developed within the organization.

\section{A Firm's External Cultural Risk Management}

A firm's external cultural-risk management is focused on risks related to the product-market positioning generated at the country-level where a company competes. A foreign market approach strategy has been widely discussed in the international business literature. Originating from the contingency theory concept of fit (Venkatraman and Camillus, 1984 [123]; Parnell, Wright, and $\mathrm{Tu}, 1996$ [90]), the research has spread to international 
marketing literature focusing on how the firm should successfully approach a country's market (De Mooij, 2010 [22]; Usunier and Lee, 2009 [118]; Kotabe and Helsen, 2009 [67]; Theodosiou and Leonidou, 2003 [115]; Zou and Cavusgil, 2002 [130]). The term international market strategy has been used broadly to refer to any involvement outside the firm's home market.

The first international market strategy can be traced in foreign markets entry mode research, which investigates how a firm should successfully compete abroad. It starts with a degree of resource commitment to the foreign market (Hill, Hwang, and Kim, 1990 [42]), such as the firm's export and contractual agreements (e.g. licensing), and ultimately moving towards strategic alliances, joint ventures, or foreign subsidiaries (Pan and Tse, 2000 [89]). It also explores the risks that the firm will bear in the host country (Hill et al., 1990 [42]; Hill and Kim, 1988 [43]) and the level of control a firm can exercise over its foreign activities (Anderson and Gatignon, 1986 [3]).

The stages theory of internationalization that was developed by Johanson and Vahlne (1977) [59], based on a study of the pattern of internationalization of Swedish firms, argues that the perceived risk associated with international expansion leads firms to enter proximate and more familiar markets first. They then gradually expand into more distant markets as experience is gained in operating in international markets. In other words, the firm's operations evolve over time as the firm gains experience and expand into international markets.

Another stream of thought looks at consumption patterns. Perhaps the most developed view of international market strategy is the standardization-adaptation dimension. A standardization strategy (Jain, 1989 [57]; Levitt, 1983 [70]; Ohmae, 1985 [87]) views a firm as pursuing a global markets' strategy by applying uniform marketing mix elements (product design, pricing, promotion and distribution) across different national markets. According to this view, customers in distant parts of the world tend to exhibit similar preferences and demand the same products. In contrast, an adaptation strategy adapts marketing mix elements to the needs of each market. Proponents of adaptation believe that markets can be sensitive to the local culture and thus, marketing must be done to conform to local tradition (Rugman and Verbeke, 2004 [98]).

For instance, Coca-Cola, a well-known advocate of global standardization, is able to use standard packaging, distribution, and brands in all of its international markets. The company sells products using standardized marketing programs to achieve a low-cost position, which is the goal of its global marketing strategy. In contrast, McDonald's, which is a proponent of adaptation, makes great efforts to blend into local cultures. In India, where local tastes are very different than those in the United States, the company crafts an entirely different menu that does not use beef, pork, or animal flavoring due to the mostly vegetarian population. In Israel, the locally owned McDonald's purchases over 80 percent of its ingredients from local producers, including 100 percent kosher meat, potatoes, lettuce, buns, and milkshake mix.

Product-market related experience is all the more important because trade barriers relating to the emergence of regional free trading blocs diminish very gradually and only in the long term. On a political map, national borders are as clear as ever and external cultural risks remain. To mitigate these risks, firms have to implement international markets' strategies cautiously, especially in culture-bound countries.

A firm might have different strategic options in structuring its approaches across different markets. They can be pursued simultaneously to the extent that they fit the cultural internal and external environments. An ERM of strategic planning includes the desired degree of involvement, the amount of resources (human and financial) that a firm is willing to devote to developing operations in international markets, its market approach strategy, and the amount of knowledge that it is needed to transfer. All these elements need to be considered at the strategic planning process with regard to the level of risk the firm is willing to consider.

\section{Final Considerations and Future Studies}

Businesses now operate in an entirely different environment when compared with just ten years ago. Risk exposure has increased and become more complex, diverse, and dynamic. The increasing cultural diversity within many organizations and their international expansion has increased their exposure to cultural risk.

There is no single standard of cultural issues management that offers all of the answers. Although a variety approaches can be adopted, there are theoretical and practical arguments for the use of ERM as an integral part of the strategic planning process in cultural risk management. This paper provides considerable support for a broad view of cultural risk management through the ERM lens.

First, the ERM approach means that a firm looks at all of the risks that it faces across all of the operations that it undertakes. These sometimes interrelated risks are assessed systematically within an integrative framework considering the whole risk management cycle, which includes risk identification, analysis, evaluation, and risk responses as a central process element. Therefore, cultural risks are not unseen or isolated and their management remains an integral part of the strategic planning process. Second, ERM involves the assignment of prioritization, ownership, completion, and monitoring of mitigating actions to manage cultural risks. Finally, this approach provides a global picture to management on how to improve business decisions and provide reasonable 
assurance regarding the achievement of their strategic objectives. Overall, through ERM mechanisms, a firm can generate benefits and mitigate the negative effects of culture.

This paper also suggests the internal and external views of cultural risk. The crafting of cultural risk management is a dynamic ongoing process that continually evolves as the firm expands into new countries and markets, requiring adaptation to new foreign market conditions and management of the internal pressures within the firm. In international business studies, many scholars tend to ignore either the external or the internal aspects of a firm's cultural factors, emphasizing only cultural diversity issues or the challenges of foreign markets. This paper suggests that cultural risk should reflect both the internal and external aspects of the firm. We refer to cultural diversity dynamics as the internal cultural risk of the firm. External cultural risks include foreign market product-market positioning issues. Accordingly, cultural risk management should consider both the out there and in here dynamics of the firm.

Finally, this paper theorizes some insights on how to manage cultural risk. Using strategy's RBV and related $\mathrm{KM}$ opens a perspective on the internal cultural risk management related to the cultural dynamics of diversity within the organization. Building on the firm's product-market positioning, or Porter's activity-based product-market view and related international markets' dynamics, this paper suggests a number of strategic moves that can potentially mitigate the firm's external cultural risks. The suggested framework incorporates cultural risk under an ERM umbrella, presents two sides of cultural risk, and draws some cultural risk management strategies. These insights could enrich the international business literature by offering a unifying conceptual framework of cultural risk management.

This paper also raised some issues relevant to the concept of cultural risk. The concept generates two related concerns: first, culture's dynamism (Holden, 2002 [50]; Søderberg and Holden, 2002 [111]; Leung and Morris, 2015 [69]), and, thus, the difficulty to measure such dynamism in order to quantify inherent risks; and second, how to measure non-financial risks (Andersen and Schroder, 2010 [2]). And if culture changes, how can a firm be prepared for such cultural frictions? There are many opportunities for more research in this area other than finding answers to the question: Is culture static or dynamic?

A globalizing business world needs suitable tools to benefit both researchers and practitioners. After an extensive survey of the literature on culture, risk, risk management, strategic management's RBV and product-market positioning, we suggest a unifying conceptual framework to guide cultural risk management practice. A firm's overall success in today's uncertain and interconnected business environment can come from its capacity to manage its internal and external cultural risks. The framework can be useful for a number of stakeholders within the professional community and can also help to guide researchers contemplating cultural risk management research. Future work should consider testing the applicability of this framework.

\section{REFERENCES}

[1] Asmussen, C. G., and Goerzen, A. (2013) 'Unpacking dimensions of foreignness: Firm-specific capabilities and international dispersion in regional, cultural, and institutional space', Global Strategy Journal, Vol. 3 No. 2, pp.127-149.

[2] Andersen, T.J, and Schroder, P.W. (2010) Strategic Risk Management Practice, Cambridge.

[3] Anderson, E., and Gatignon, H. (1986) 'Modes of foreign entry: A transaction cost analysis and propositions', Journal of International Business Studies, Vol.17, pp.1-26.

[4] Appelbaum, S. H., Roberts, J., and Shapiro, B. T. (2009) 'Cultural Strategies in M\&As: Investigating Ten Case Studies', Journal of Executive Education, Vol. 8 No.1, pp. $33-58$.

[5] Asch, S. E. (1956) 'Studies of independence and conformity: I. A minority of one against a unanimous majority,' Psychological Monographs, Vol.70 No. 9, pp.1-70.

[6] Ashby, W.R. (1956) An Introduction to Cybernetics, London: Chapman and Hall.

[7] Aubert, B. and Bernard, J-G. (2004) 'Mesure Intégrée du Risque dans les Organisations', Les presses de l'université de Montréal.

[8] Barkema, H. G., Bell, J. H., and Pennings, J. M. (1996) 'Foreign entry, cultural barriers, and learning', Strategic Management Journal, Vol. 17, pp. 151-166.

[9] Barkema, H. G., Shenkar, O., Vermeulen, F., and Bell, J. H. (1997) 'Working abroad, working with others: How firms learn to operate international joint ventures', Academy of Management Journal, Vol. 40, pp. 426-442.

[10] Barney, J.B. (1985) 'Organizational culture: can it be a source of sustained competitive advantage?' Academy of Management Review, Vol. 11 No. 3, pp. 656-665.

[11] Bishop, M. (1996) 'A game of risk', The Economist, Vol. 338 No. 7952 , pp. 22.

[12] Bivens, K., and Lowell, E. (1966) Joint Ventures with Foreign Partners, New York: The Conference Board.

[13] Boyle, B., Nicholas, S., and Mitchell, R. (2012) 'Sharing and developing knowledge of organization culture during international assignments', International Journal of Cross-Cultural Management, Vol. 12 No.3, pp. 361-378.

[14] Brannen, M. Y. (2004) 'When Mickey loses face: Recontextualization, semantic fit, and the semiotics of foreignness', Academy of Management Review, Vol. 29, pp. 
$593-616$.

[15] Buchtel, E. E., and Norenzayan, A. (2008) 'Which should you use, intuition or logic? Cultural differences in injunctive norms about reasoning', Asian Journal of Social Psychology, Vol. 11 No. 4, pp. 264-273.

[16] Caprar, D. (2011) 'Foreign locals: A cautionary tale on the culture of MNC local employees', Journal of International Business Studies, Vol. 42 No. 5, pp. 608-628.

[17] Carney, M. (2005) Globalization and the renewal of Asian business networks. Asia Pacific Journal of Management, 22(4): 337-354.

[18] Chapman, R. (2011) Simple Tools and Techniques for Enterprise Risk Management, 2nd ed., Wiley.

[19] Chelariu, C, Bello, D. C, and Gilliland, D. I. (2006) 'Institutional antecedents and performance consequences of influence strategies in export channels of Eastern European transition economies', Journal of Business Research, Vol. 59 No. 5 , pp. $525-534$.

[20] Child, J., and Markoczy, L. (1993) 'Host-country managerial behavior and learning in Chinese and Hungarian joint ventures', Journal of Management Studies, Vol. 30, pp 611-631.

[21] Delios, A., and Beamish, P. W. (2001) 'Survival profitability: The roles of experience and intangible assets in foreign subsidiary performance', Academy of Management Journal, Vol. 44, pp. 1028-1038.

[22] De Mooij, M. (2010) Global marketing and advertising: Understanding cultural paradoxes, 3rd ed., Sage Publications, Thousand Oaks.

[23] Denzin, N., and Lincoln, Y. (2000) Handbook of Qualitative Research, SAGE Publications. Thousand Oaks.

[24] D'Iribarne, P. (2009) 'Conceptualising national cultures: an anthropological perspective', European Journal of International Management, Vol. 3 No. 2, pp. 167-175.

[25] Doole, I., and Lowe, R. (2008) International Marketing Strategy, 5th ed., Cengage Learning EMEA.

[26] Dunning, J.H. (1993) Multinational Enterprises and the Global Economy, Wokingham: Addison-Wesley.

[27] Dupuis, J.P., (2014) 'New approaches in cross-cultural management research: The importance of context and meaning in the perception of management styles', International Journal of Cross Cultural Management, Vol.14 No.1, pp. 67-84.

[28] Easterby-Smith, M., and Lyles, M. (2006) Handbook of Organizational Learning and Knowledge Management, Chichester: Blackwell Publishing.

[29] Fang, Y., Wade, M., Delios, A., and Beamish, P.W. (2007) 'International diversification, subsidiary performance, and the mobility of knowledge resources', Strategic Management Journal, Vol. 28 No.10, pp. 1053-64.

[30] Fang, Y., Frank Jiang, G.L., Makino, S., and Beamish, P.W. (2010) 'Multinational Firm Knowledge, Use of Expatriates, and Foreign Subsidiary Performance', Journal of Management Studies, Vol. 47 No. 1, pp. 27-54.
[31] Farjoun, M. (1998) 'The independent and joint effects of the skill and physical bases of relatedness in diversification', Strategic Management Journal, Vol. 19, pp. 611-630.

[32] Firsova, N., Vaghely, I., and Arcand, G. (2015) Does cross cultural risk management create competitive advantage? 9th Biennial Congress of the International Academy of Intercultural Research, Bergen, Norway.

[33] Fishbein, M., and Ajzen, I. (1975) Belief, attitude, intention, and behavior: An introduction to theory and research, Reading, MA: Addison-Wesley.

[34] Fraser, J., and Simkins, B. (2010) Enterprise Risk Management: Today's Leading Research and Best Practices for Tomorrow's Executives, Wiley.

[35] Gerhart, B., and Fang, M. (2005) 'National culture and human resource management: assumptions and evidence', The International Journal of Human Resource Management, Vol. 16 No. 6, pp. 971-986.

[36] Gioia, D.A. (1986) Symbols, Scripts, and Sensemaking: Creating Meaning in the Organizational Experience. In: Gioia, D.A. and Sims, H. (eds) The Thinking Organization: Dynamics of Organizational Social Cognition, San Francisco: Jossey-Bass, pp.49-74.

[37] Gioia, D.A., and Manz, C.C. (1985) 'Linking Cognition and Behavior: A Script Processing Interpretation of Vicarious Learning', The Academy of Management Review, Vol. 10 No. 3, pp. 527-539.

[38] Gioia, D.A., and Poole, P.P. (1984) 'Scripts in Organizational Behavior', The Academy of Management Review, Vol. 9 No. 3, pp. 449-459.

[39] Ghoshal, S. (1987) 'Global Strategy: An Organizing Framework', Strategic Management Journal, Vol. 8 No. 5, pp. 425-440.

[40] Gomez-Mejia, L. R., and Palich, L. E. (1997) 'Cultural diversity and the performance of multinational firms', Journal of International Business Studies, Vol. 28, pp. 309335 .

[41] Herskovits, M. (1967) Les bases de l'anthropologie culturelle, Paris : François Maspero.

[42] Hill, C., Hwang, P., and Kim, W.C. (1990) 'An eclectic theory of the choice of international entry mode', Strategic Management Journal, Vol. 11, pp. 117-128.

[43] Hill, C., and Kim, W.C. (1988) 'Searching for a dynamic theory of the multinational enterprise: A transaction cost model', Strategic Management Journal, Vol. 9, pp. 93194.

[44] Hill, C. W. L. (2007) 'Digital piracy: Causes, consequences, and strategic responses', Asia Pacific Journal of Management, Vol. 24 No. 1, pp. 9-25.

[45] Hillson, D., and Murray-Webster, A. (2007) Understanding and Managing Risk Attitude, 2nd ed, Gower.

[46] Hofstede, G. (1991) Cultures and organizations, London: McGraw Hill.

[47] Hofstede, G. (2001) Culture Consequences, 2nd ed., SAGE Publications, Thousand Oaks. 
[48] Hofstede, G., Van Deusen, C, Mueller, C, Charles, T., and Business Goals Network (2002) 'What goals do business leaders pursue? A study in fifteen countries', Journal of International Business Studies, Vol. 33 No. 4, pp. 785-803.

[49] Hofstede, G., Hofstede J.G., and Minkov, M. (2010) Cultures and Organizations: Software of the Mind. Intercultural Cooperation and its Importance for Survival, New York: McGraw Hill.

[50] Holden, N. (2002) Cross-Cultural Management: A Knowledge Management Perspective, Pearson.

[51] Hopkin, P. (2012) Fundamentals of Risk Management: Understanding, Evaluating and Implementing Effective Risk Management, 2nd ed., Kogan Page Ltd.

[52] House, R.J., Hanges, P.J., Javidan, M., Dorfman, P., and Gupta, V. (2004) Culture, leadership, and organizations. The GLOBE study of 62 societies, Sage Publications, Thousand Oaks.

[53] Hunt, B. (2001) Issue of the Moment: The Rise and Rise of Risk Management. In Mastering Risk Volume 1: Concepts, Pearson Education Ltd, UK.

[54] Hymer, S. (1976) The International Operations of Nation Firms: A Study of Foreign Direct Investment. Cambridge: MLT Press.

[55] Ingram, P., and Silverman, B. (2002) Introduction. In P. Ingram and B. Silverman (eds.), The new institutionalism in strategic management, Amsterdam, Elsevier, pp.1-30.

[56] ISO Guide 73. (2009) www. iso.org.

[57] Jain, S.C. (1989) 'Standardization of International Strategy: Some Research Hypotheses,' Journal of Marketing, Vol.53 No 1, pp. 70-79.

[58] Jehn, K., Northcraft, G., and Neale, M. (1999) 'Why differ ences make a difference: A field study of diversity, conflict and performance in work groups', Administrative Science Quarterly, Vol. 44, pp. 41-763.

[59] Johanson, J., and Vahlne, J. E. (1977) 'The internationalization process of the firm: A model of knowledge development and increasing foreign market commitments', Journal of International Business Studies, Vol. 8, pp. 23-33

[60] Kaplan, S., and Garrick, J. (1981) 'On the Quantitative Definition of Risk', Risk Analysis, Vol. 1 No. 1, pp. 11-27.

[61] Karjalainen, H. (2010) 'Can multicultural human resources management problems be solved by an organisational culture? Management international, Vol. 14 No. 4, pp. 99114.

[62] Keegan, W. J. (2002) Global Marketing Management, USA: Prentice Hall.

[63] Killing, J. (1983) Strategies for Joint Ventures Success, London: Croom Helm

[64] Kogut, B., and Singh, H. (1988) 'The Effect of National Culture on the Choice of Entry Mode', Journal of International Business Studies, Vol. 19 No. 3, pp. 411-432.

[65] Kostova, T. (1999) 'Transnational transfer of strategic organizational practices: A contextual perspective',
Academy of Management Review, Vol. 24, pp. 308-324.

[66] Kostova, T., and Roth, K. (2002) 'Adoption of an organizational practice by subsidiaries of multinational corporations: Institutional and relational effects', Academy of Management Journal, Vol. 45, pp. 215-233.

[67] Kotabe, M., and Helsen, K. (2009) Global Marketing Management, New York: Wiley.

[68] Kroeber, A.L., and Kluckhohn, C. (1952) 'Culture: A Critical Review of Concepts and Definition', Papers of the Peabody Museum of Archeology and Ethnology, Vol. 47 No. 1, pp. 1-223.

[69] Leung, K., and Morris, M. (2015) 'Values, Schemas, and Norms in the Culture-Behavior Nexus: A Situated Dynamics Framework', Journal of International Business Studies, Vol. 46 No. 9, pp. 1028-1050.

[70] Levitt, T. (1983) 'The Globalization of Markets', Harvard Business Review, 61 (May/June), pp. 92-102.

[71] Lipovetsky, G. (2004) Les temps hypermodernes, Paris: Grasset.

[72] Lu, J., and Beamish, P. (2006) 'SME internationalization and performance: Growth vs. profitability', Journal of International Entrepreneurship, Vol. 4 No. 1, pp. 27-48.

[73] Luo, Y., and Mezias, J.M. (2002) 'Liabilities of Foreignness: Concepts, constructs, and consequences', Journal of International Management, Vol. 8 No. 3, pp. 217-221.

[74] Luo, Y., and Peng, M. W. (1999) 'Learning to compete in a transition economy: Experience, environment, and performance', Journal of International Business Studies, Vol. 30, pp. 269-296.

[75] Luo, Y., and Shenkar, O. (2011) 'Toward a perspective of cultural friction in international business', Journal of International Management, Vol. 17, pp.1-14.

[76] Luria, A. R. (1976) Cognitive Development: Its Cultural and Social Foundations, Harvard University Press, Cambridge, MA

[77] Malinowski, B. (1968) Une théorie scientifique de la culture et autres essais, Paris: Maspero.

[78] March, J., and Shapira, Z. (1987) 'Managerial Perspectives on Risk and Risk Taking', Management Science, Vol. 33 No. 11, pp. 1404-1418.

[79] Miller, K.D. (1992) 'A Framework for Integrated Risk Management in International Business', Journal of International Business Studies, Vol. 23, pp. 311-331.

[80] Miller, K.D. and Bromiley, P. (1990) 'Strategic Risk and Corporate Performance: An Analysis of Alternative Risk Measures', The Academy of Management Journal, Vol. 33 No. 4, pp. 756-779.

[81] Nakos, G., and Brouthers, K.D. (2002) 'Entry mode choice of SMEs in Central and Eastern Europe', Entrepreneurship Theory and Practice, pp. 47-63.

[82] Nathan, G. (2015) 'A non-essentialist model of culture: Implications of identity, agency and structure within multinational/multicultural organizations', International Journal of Cross Cultural Management, Vol. 15 No. 1, pp. 
101.

[83] Nonaka, I., and Takeuchi, H. (1995) the Knowledge Creat ing Company, New York: Oxford University Press.

[84] Nonaka, I., and Von Krogh, G. (2009) Tacit Knowledge and Knowledge Conversion: Controversy and Advancement in Organizational Knowledge Creation Theory. Organization Science, Vol. 20 No. 3, pp. 635-652.

[85] Norenzayan, A., Smith, E. E., Kim, B. J., and Nisbett, R. E. (2002) 'Cultural preferences for formal versus intuitive reasoning', Cognitive Science, Vol. 26 No. 5, pp. 653-684.

[86] North, D.C. (1990) Institutions, institutional change, and economic performance, Cambridge, MA: Harvard University Press.

[87] Ohmae, K. (1985) Triad Power: The Coming Shape of Global Competition, New York: The Free Press.

[88] O'Reilly, C., Snyder, R., and Boothe, J. (1993) 'Effects of executive team demography on organizational change' In G. P. Huber and W. H. Glick, Organizational Change and Redesign: Ideas for Insights for Improving Performance, New York: Oxford University Press

[89] Pan, Y., and Tse, D. (2000) 'The hierarchical model of market entry modes', Journal of International Business Studies, Vol. 31 No. 4, pp. 535-554.

[90] Parnell, J. A., Wright, P., and Tu, H. S. (1996) 'Beyond the strategy-performance linkage: The impact of the strategy-organization-environment fit on business performance', American Business Review, Vol. 14 No. 2, pp. $41-50$.

[91] Pelled, L. (1996) 'Demographic diversity, conflict and work group outcomes: An intervening process theory', Organization Science, Vol. 17, pp. 615-631.

[92] Peng, M.W., Wang, D., and Jiang, Y. (2008) 'An Institution-Based View of International Business Strategy: A Focus on Emerging Economies', Journal of International Business Studie, Vol. 39 No. 5, pp. 920-936.

[93] Porter, M.E. (1979) 'How Competitive Forces Shape Strategy', Harvard Business Review, Vol. 3 No. 4, pp.137145 .

[94] Porter, M.E. (1980) Competitive Strategy: Techniques for Analyzing Industries and competitors, New York: The Free Press.

[95] Prahalad, C.K., and Hamel, G. (1990) 'The Core Competence of the Corporation', Harvard Business Review, Vol. 5 No. 6 pp. 79-91.

[96] Redding, G. (2005) 'The thick description and comparison of societal systems of capitalism, Journal of International Business Studies, 36(2): 123-155.

[97] Rosaldo, R. (1997) Whose cultural studies? Cultural studies and the disciplines. In Gibian, P. (ed.), Mass cultural and everyday life (pp.26-33). New York: Routledge.

[98] Rugman, A., and Verbeke, A. (2004) A perspective on regional and global strategies of multinational enterprises. Journal of International Business Studies, 35(1): 3-18.

[99] Rugman, A.M., and Doh, J. (2008) Multinationals and
Development. New Haven. CT: Yale University Press.

[100] Sackmann, S.A., Phillips, M.E., Kleinberg, M.J., and Boyacigiller, N.A. (1997) 'Single and multiple cultures in international cross-cultural management research', In: Sackmann, S.A. (eds) Cultural Complexity in Organizations: Inherent Contrasts and Contradictions, Sage Publications, Thousand Oaks, pp.14-49.

[101] Sanchez, R. (2001) Knowledge management and organizational competence, Oxford: Oxford University Press.

[102] Schwartz, S.H. (2007) 'A theory of cultural value orientations: explication and applications', In: Esmer, Y., and Pettersson, T. (eds) Measuring and Mapping Cultures: 25 years of Comparative Value Surveys, Leiden: Brill Academic Publishers, pp.33-78.

[103] Scott, W.R. (1995) Institutions and organizations, SAGE Publications, Thousand Oaks.

[104] Shenkar, O. (2001) 'Cultural distance revisited: Towards a more rigorous conceptualization and measurement of cultural differences', Journal of International Business Studies, Vol. 32 No. 3, pp. 519-535.

[105] Shenkar, O., Luo, Y., and Yeheskel, O. (2008) 'from "distance" to "friction": Substituting metaphors and redirecting intercultural research', Academy of Management, Vol. 33 No. 4, pp. 805-923.

[106] Shenkar, O., and Zeira, Y. (1992) 'Role conflict and role ambiguity of chief executive officers in international joint ventures', Journal of International Business Studies, Vol. 23 , pp. 55-75.

[107] Sherif, M. (1936) The psychology of social norms, Oxford: Harper.

[108] Schuler, R,S., and Rogovsky, N. (1998) 'Understanding Compensation Practice Variations Across Firms: The Impact of National Culture', Journal of International Business Studies, Vol. 29 No. 1, pp. 159-177.

[109] Sivakumar, K., and Nakata, C. (2001) 'The Stampede Toward Hofstede's Framework: Avoiding the Sample Design Pit in Cross-Cultural Research', Journal of International Business Studies, Vol. 32 No. 3, pp. 555.

[110] Shimpi, P. (2001) Integrating Corporate Risk Management, Texere.

[111] Søderberg, A.M., and Holden, N. (2002) 'Rethinking cross cultural management in a globalizing business world', International Journal of Cross Cultural Management, Vol. 2 No. 1, pp. 103-121.

[112] St-Pierre, J., and Bahri, M. (2006) 'The use of the accounting beta as an overall risk indicator for unlisted companies', Journal of Small Business and Enterprise Development, Vol. 13 No. 4, pp. 546-561.

[113] Taleb, N. (2010) The Black Swan: Second Edition: The Impact of the Highly Improbable: With a new section: On Robustness and Fragility, Random House Trade Paperbacks.

[114] Thatcher, S., and Jehn, K. (1998) 'A model of group diversity profiles and categorization processes in bicultural organizational teams', In A. Mannix, M., Neale and D. Gruenfeld, Research on Managing Group and Teams, Stamford, CT: JAI Press. 
[115] Theodosiou, M., and Leonidou, L.C. (2003) 'Standardization versus adaptation of international marketing strategy: an integrative assessment of the empirical research', International Business Review, Vol. 12, pp. 141-171.

[116] Trompenaars, F., and Hampden-Turner, C. (1998) Riding The Waves of Culture: Understanding Diversity in Global Business, London: Nicholas Brealey Publishing.

[117] Tylor, E.B. (1924) Primitive Culture, Gloucester: Smith.

[118] Usunier, J.C., and Lee, J. A. (2009) Marketing across Cultures, 5th ed., New Jersey: Pearson, Prentice Hall.

[119] Vaghely, I., and Julien, P.A. (2010) 'Are Opportunities Recognized or Constructed? An Information Perspective on Entrepreneurial Opportunity Identification', Journal of Business Venturing, Vol. 25 No. 1, pp. 73-8.

[120] Van Knippenberg, D., De Dreu, C.K.W., and Homan, A.C. (2004) 'Work Group Diversity and Group Performance: An Integrative Model and Research Agenda', Journal of Applied Psychology, Vol. 89 No. 6, pp. 1008-1022.

[121] Vassolo, R. S., Anand, J., and Folta, T. B. (2004) 'Non-additivity in portfolios of exploration activities: A real options-based analysis of equity alliances in biotechnology', Strategic Management Journal, Vol. 25, pp. 1045-106

[122] Vaughan, E. J. (1997) Risk Management, Wiley.
[123] Venkatraman, N., and Camillus, J.C. (1984) 'Exploring the Concept of "Fit" in Strategic Management', The Academy of Management Review, Vol. 9 No. 3, pp.513-525.

[124] Vygotsky, L.S. (1962) Thought and Language, Cambridge, MA: MIT Press.

[125] Waring, A., and Glendon, A.I. (1998) Managing Risk: Critical Issues for Survival and Success into the 21 Century, Thompson.

[126] Yeganeh, H. (2011) 'A generic conceptualization of the cultural distance index, Journal of Strategy and Management, Vol. 4 No. 4, pp. 325-346.

[127] Zaheer, S. (1995) 'Overcoming the liability of foreignness', Academy of Management Journal, Vol. 18, pp. 439-464.

[128] Zaheer, S., and Mosakowski, E. (1997) 'The dynamics of the liability of foreignness: A global study of survival in financial services', Strategic Management Journal, Vol. 18, pp. 439-464.

[129] Zhou, K. Z., Tse, D. K., and Li, J. J. (2006) 'Organizational changes in emerging economies: Drivers and consequences', Journal of International Business Studies, Vol. 37 No. 2, pp. 248-263.

[130] Zou, S., and Cavusgil, S.T. (2002) 'The GMS: A broad conceptualization of global marketing strategy and its effect on firm performance', Journal of Marketing, Vol. 66 No. 4 , pp. $40-56$ 